\title{
Making Hay While the Sun Shines: envisioning New Zealand's state-diaspora relations
}

\author{
Alan Gamlen
}

\section{Introduction}

The diaspora is a long-term feature of New Zealand's migration system and its political landscape. Yet the New Zealand government does not have a coherent approach towards it. Why not? It cannot be because nothing important is happening: around $850 \mathrm{New}$ Zealanders emigrate in the average week, and around one in five New Zealanders now lives abroad. Moreover, while not a first-order policy issue in itself, this is important across a range of policy areas, and occasionally requires urgent government attention. A more likely explanation for the absence of coherence is that New Zealand still sees itself as a migrant-receiving country, and that the diaspora has been a political hot potato, making levelheaded debate difficult.

With some heat temporarily dissipated from the issue, it seems an appropriate time to consider long-term scenarios. This article suggests that the diaspora is a long-term social, political and economic reality for New Zealand, and that it therefore deserves a more coherent, holistic and long-term approach from the New Zealand Government. Moreover, it suggests that good state-diaspora relations can mitigate some of the political and economic costs of sustained emigration. With this in mind, the article presents three scenarios to illustrate what kinds of relationship the New Zealand Government could have with the diaspora. It is hoped that these scenarios might contribute to more strategic thinking in this area.

\section{A New Zealand 'diaspora'?}

In the average year since 1979, 43,976 New Zealand citizens have departed the country, while only 23,398 have arrived (Statistics New Zealand, 2006). As a result, a comparatively large proportion of New Zealanders live abroad. Verifiable bare-minimum estimates (known to be undercounts ${ }^{1}$ ) put the number of New Zealanders abroad at between 459,322 (Bryant \& Law, 2004) and 528,597 (Migration DRC, 2007). Scholars guesstimate between 600,000 and 850,000 (Bedford, 2001; Hugo, Rudd \& Harris, 2003). Estimates of 1 million or more regularly appear in the media (Dusevic, 2006; see also www.nzedge.com/intro/). The number of New Zealanders abroad has never been accurately counted and remains unknown.

The key question is, do these people still actively identify themselves as New Zealanders, despite lengthy dispersion? In other words, are they a 'diaspora'2 (Butler, 2001)? New data collected in early 2006 by the governmentsupported Kiwi Expatriate Association (Kea) sheds some new light on this question. Eighteen thousand people completed Kea’s 'Every One Counts' questionnaire, which was directed at 'Kiwi expatriates' and distributed by a chain email. This method ensured that the sample was self-selective of people who identified as New Zealanders and were actively connected enough to receive the survey through their email networks. Respondents' most common transnational activities were social, such as staying in touch with family and friends in New Zealand. Transnational activities of a more civic nature were also fairly common - things like reading newspapers and websites, belonging to New Zealand organisations, and keeping in contact through government sources. Transnational economic activities were relatively uncommon, although many respondents held bank accounts or other securities in New Zealand.

The Kea respondents were certainly well dispersed: though concentrated in three main locations - the UK

1 For discussion of problems counting expatriates, see Dumont and Lemaître (2004) and Hugo (2006a).

2 Butler (2001) identifies four defining features of diaspora on which most theorists agree: dispersion across one or more locations, self-identification with a common group identity, maintenance of a relationship to a homeland, and persistence over two or more generations. 
and Ireland (48.9\%), the USA (11.6\%) and Australia (26.3\%) - they were spread across more than 150 countries. Many had been away for long periods, and wrote detailed comments on their identity. In some cases they eulogised national symbols, such as the All Blacks, the country's 'nuclear free' stance and its natural beauty. In other cases they expressed loyalty mixed with frustration, condemning things like the tax system and infrastructure, political correctness, and a range of other ways in which people felt New Zealand had ruined a perfectly good country.

Their ambivalence highlights an important question: does or will New Zealand identity persist beyond the first generation of emigrants? The survey methodology was inconclusive, but only around 5\% of Kea respondents were New Zealanders by descent (as opposed to birth or 'naturalisation'). Whether this ambiguity disqualifies use of the word 'diaspora' in the New Zealand case depends largely on one's theoretical persuasions. Theorists are split on the question of whether persistence across generations is a defining characteristic of diasporas, with 'classical' theorists of the Jewish case arguing that it is, and contemporary theorists of transnationalism and globalisation not insisting on this point (for further discussion see Butler, 2001; Hugo, 2006a; Reis, 2004).

Notwithstanding theoretical quibbles, the Kea data shows that there is a New Zealand diaspora numbering at least 18,000 people - and it seems likely that they are selective of a much larger 'transnational New Zealand' population.

\section{Why does the diaspora matter?}

The New Zealand diaspora is unlikely to become a 'firstorder' policy issue. However, it deserves higher priority attention than it currently receives, and this attention could be more coherent, holistic and long-term. As a benchmark, it is worth noting that the Australian diaspora is proportionally smaller than the New Zealand diaspora, ${ }^{3}$ yet the Australian case has been characterised by a more sophisticated debate involving examination of more options (Australian Senate, 2005; Betts, 2006; Carli, 2006; Fedi, 2006; Fullilove \& Flutter, 2004; Hugo, 2005, 2006a, 2006b; Hugo et al., 2003; see also www.southern-crossgroup.org). Nor is Australia alone amongst developed nations in treating the issue seriously (see, for example, Cowen, 2002; Sriskandarajah \& Drew, 2006).
Australian demographer Graeme Hugo (Hugo, 2006a) has outlined a number of reasons why the Australian 'diaspora' matters. The first relates to national identity, also a strategic priority for the New Zealand government. Taking into account migrants and their relationships with both origin and receiving states, social scientists in general are increasingly being forced to think outside the square of the nation state when they theorise society, using the so-called 'transnational lens' to analyse social dynamics that span national borders (Basch, Schiller \& Szanton Blanc, 1994). As Hugo puts it, the country's geographical borders do not necessarily delimit its national population (Hugo, 2006b).

This point cuts deep into New Zealand's relatively 'new and fractured' (Spoonley, Bedford \& Mcpherson, 2003) national identity. Consider, for example, that being Māori abroad involves a different formal relationship with 'home' than being a New Zealander abroad. New Zealand citizenship is 'earned' through a mixture of ancestral, birth and residence criteria, whereas formal membership in Māori society is inherited through whakapapa (genealogy). ${ }^{4}$ Some groups might argue that current national identity legislation neither reflects nor affects who is and who is not Māori, and that all Māori in diaspora should be able to return to Aotearoa, their turangawaewae (home ground), even if they are not New Zealand citizens. Without necessarily advocating this view, one can discern both legal and normative arguments which might sustain it.

A legal argument for non-citizen Māori return could begin from articles two and three of the Treaty of Waitangi. Article the second 'guarantees to the Chiefs and Tribes of New Zealand and to the respective families and individuals thereof the full exclusive and undisturbed possession of their Lands and Estates Forests Fisheries and other properties which they may collectively or individually possess so long as it is their wish and desire to retain the same in their possession'. This clause might be interpreted as a guarantee that

3 Census estimates suggest that the Australian diaspora constitutes less than $5 \%$ of the Australian-born, while expatriates are around $15 \%$ of all New Zealand-born; around $25 \%$ of New Zealand's skilled workforce resides abroad. While not unusually large in comparison to the diasporas of the Pacific Island micro-states, which send many migrants to New Zealand, New Zealand's own diaspora is the second largest in the OECD after Ireland's.

4 Proving some Māori ancestry is a necessary and sufficient condition for being recognised as Mãori. 
Māori customs of kin-based membership and property rights will be protected in perpetuity by the state. Article the third of the Treaty grants Māori 'all the Rights and Privileges of British Subjects' (emphasis added), as opposed to the rights and privileges of New Zealand citizens. In 1840 when the Treaty was signed, the rights of British subjects included the right to come and go from New Zealand at will, and the legal category of New Zealand citizen did not exist. The latter was formed in the mid-twentieth century through decisions by the British and New Zealand governments, and confers more restricted mobility rights. It might be argued that these decisions did not honour the agreements in the Treaty, were not preceded by adequate consultation with Māori, and therefore do not legitimately limit the ability of non-citizen Māori to reside on their lands.

This technical argument is far from clear cut, but draws emotive strength from norms about postcolonial reparative justice, which underpin broadly similar claims in New Zealand on a regular basis. A more explicit normative argument could begin from theories of multicultural citizenship (Kymlicka, 1995). For example, Kymlicka argues that there are normative reasons why the state should provide minorities with 'external protection' from decisions made by the wider society which would otherwise restrict the liberty of minorities to maintain their cultural practices. Some people might argue that Māori residence on tribal land is a cultural practice that should be - or should have been - protected from external decisions to alter national identity legislation. What is particularly unsettling about this line of argument is that many liberal multiculturalists have campaigned vociferously against ethnic citizenship criteria (in receiving states), but here is a liberal multicultural argument for ethnic citizenship (in sending states). Perhaps this paradox illustrates that it is just as excessive to completely separate ethnicity and citizenship as it is to equate them.

Through the special ministerial grant of citizenship, New Zealand identity legislation does provide a channel for recognising intergenerational ties (Identity Policy Team, 2006a, 2006b). However, the 'rights' of non-citizen Māori still raise important questions. Must national identity legislation apply consistently to all cultural groups in increasingly diverse societies? Are expatriate Māori the only New Zealanders with significant intergenerational links to the country? Which models of belonging are appropriate for New Zealand: those that attach to territory, or those that attach to people? Is inherited national identity relevant in a globalising world? If so, should governments encourage citizenship by descent by emphasising the benefits of 'staying Kiwi'? What exactly are these benefits if one lives abroad, and are they consistent across ethnic groups? Systematically and cooperatively thinking through such questions in the context of a focused debate on state-diaspora relations would seem to fit squarely within the current government's strategic focus on national identity.

For Hugo (2006a) the diaspora also matters because diasporas can and do play a significant role in economic and social development in their home countries (also see Levitt, 1998; Newland \& Patrick, 2004; Van Hear, Pieke \& Vertovec, 2004; Vertovec, 2004). New Zealand is probably no exception, though the evidence is patchy. For example, it is well known that the expatriate experience has played a vital role in the development of a distinctive New Zealand literary and artistic culture (Belich, 2001), though this has not been the subject of social science research. There is increasing recognition that for young New Zealanders the overseas experience is an expected element of career development (for example, see Carr, Inkson \& Thorn, 2005), yet there are no studies of the impact of overseas experience on career achievement or local economic development in New Zealand. Anecdotally we know that the Kiwi OE - like most labour migration flows - is often a route to social mobility and home ownership at home. Yet, despite a national debate about the impacts of net migration on inflation and housing prices, there is no discussion of the housing-market impacts of returning New Zealanders, who form a major component of our migration inflows. Indeed, despite all that we know from the international literature about the economic impacts of emigration at source, no study of New Zealand expatriates' financial transfers appears to exist. Various government strategies have emphasised how transnational engagement with expatriates provides opportunities for economic growth and transformation, and from other examples it is easy to see how this thinking has a basis in fact. In order for it to bear fruit, better qualitative and quantitative understanding is needed regarding the existing economic, political and sociocultural transnationalism of New Zealanders. 
The diaspora matters to Hugo because it is becoming more self-aware and organised. As the Kea survey demonstrates, this is also happening in New Zealand to the extent of it forming a loose lobby group through organisations such as Kea and the New Zealand Institute. If this trend of increasing coherence continues, successive governments will face not only increasing lobby pressure to form policies towards the diaspora, but also electoral pressure to seek constituencies within it - as has happened in many other countries with large diasporas. Overseas campaigning has already become an element of national elections in New Zealand. For example, the Labour Party increased their overseas vote by $40 \%$ in 2002 partly due to Australian-based trade unions campaigning on their behalf. A future increase in political participation amongst overseas voters could potentially transform New Zealand's political landscape.

However, emigration and the diaspora do not merely flash into existence at election time. This is a population that has accrued over many decades, is actively involved in the same social, economic and political fields as the New Zealand state, and will not disappear any time soon. Fewer than $23 \%$ of Kea survey respondents had definite return plans, while more than $50 \%$ didn't know, probably wouldn't return or definitely planned not to. Nor can the 'moral panic' over 'brain drain' which peaked in 2000 (Davenport, 2004) - and forced a reaction from the government - be considered an isolated event. The 2000 episode maintained a steady level of media prominence between 1999 and 2001, and, since the late 1980s, concerns about emigration (lumped under the heading of 'brain drain') have never been far below the surface (Bain, 1996; Button, 1988; Chamberlain, 2004, 2005; Collins, 2002; Davis \& Thomas, 2005; Deutsche Bank, 2003; Gamlen, 2005; Jaspan \& Colebatch, 2007; McCrone, 2007; McCurdy, 2004; New Zealand Herald, 2007). A mini brain drain debate flares up at peaks and troughs in net migration cycles, during debates over race relations, and at moments of economic downturn. In between times, emigration and diaspora are intimately bound up with angst over long-term strategic issues like New Zealand's ageing population (Bedford, Ho \& Hugo, 2003), fears of losing contact with children and grandchildren living abroad, ${ }^{5}$ and the taxation system.

In short, while not a first-order priority, the diaspora is a long-term feature of both the migration system and the political landscape in New Zealand, and at specific points it is an issue of acute political importance. A deliberate approach to fostering and managing good relations with the diaspora could offset the economic costs of emigrants taking their business elsewhere, and the political costs from accusations of causing or allowing a 'brain drain'. It would make sense if New Zealand's long-term state planning reflected this.

\section{Tactics without strategy}

However, the current approach to the New Zealand diaspora is one of tactics without strategy. The diaspora is affected by a collection of activities dispersed across government, some of which are old and all but forgotten, and others of which are new and prototypical. It is useful to separate these mechanisms into three simple categories, which are discussed below: extracting benefits, extending rights, and capacity building (Gamlen, 2006). ${ }^{6}$

\section{Extracting benefits}

Expatriates have always been called upon to contribute to New Zealand's export development and promotion activities, which have developed over the past 30 years and are currently managed by New Zealand Trade and Enterprise (NZTE). They have done so both formally (through mechanisms such as advisory boards) and informally (through access to in-market social and professional networks).

New ideas about extracting benefits from expatriates came out of the government's 2002 Growth and Innovation Framework strategy (GIF), which was developed in partnership with private sector stakeholders - including prominent expatriates (Office of the Prime Minister, 2002) - and aimed to raise per capita GDP performance. These ideas have precipitated two main initiatives, which have carried over into the current government's strategic focus on economic transformation. The first is a drive to stimulate return migration. The Department of Labour's (DoL) threeyear, approximately $\$ 3 \mathrm{~m}$ Expatriates Programme was

5 I am grateful to Paul Callister for suggesting this point.

6 These categories extend the predominant trend in scholarly literature on diaspora policies, which views them through the lens of national membership beyond the national territory. As their titles suggest, the following publications are indicative: Barry, 2006; Bauböck, 1994, 2005; Betts, 2006; Fitzgerald, 2006; Goldring, 1998; Guarnizo, 1994; Laguerre, 1999; Lee, 2004; Smith, 2003a, 2003b). 
established in 2005 and focuses on keeping expatriates in touch with New Zealand, especially with a view to attracting them back. This workstream is aligned with two major fiscal incentives aimed at return and retention of 'talent'. The first is a five-year tax holiday on foreign income sources for returning long-term expatriates in high income brackets, with administrative and operating costs of approximately $\$ 1.1 \mathrm{~m}$ in year one and $\$ 330,000$ thereafter, and estimated annual fiscal costs of $\$ 10-13 \mathrm{~m}$. The second provides interest-free student loans for $\mathrm{New}$ Zealand residents at an annual cost of around $\$ 300 \mathrm{~m}$, and a 'fresh start' for overseas borrowers - including an amnesty on missed-repayment penalties - at an estimated net fiscal cost of $\$ 15 \mathrm{~m}$ per annum.

The second (much smaller) initiative focuses on keeping expatriates connected and contributing to New Zealand from afar. For the eight-year period from 2002 to 2010, the government (mainly through the Ministry of Economic Development (MED)) has so far approved around $\$ 2.4 \mathrm{~m}$ in infrastructure grants to the Kiwi Expatriate Association. Kea is a public-private sponsored network of 'talented' expatriates aiming to increase connections between New Zealanders in order to further New Zealand's economic interests. Its infrastructure consists of an online database of around 20,000 expatriates, along with smaller local chapters in key offshore regions, several of which employ a paid manager. Kea is aligned with two NZTE programmes: 'World Class New Zealand' (WCNZ) and 'Beachheads'. Founded in 2001, WCNZ was initially funded at $\$ 2.25 \mathrm{~m}$ per annum. Its funding now reduced to $\$ 1.17 \mathrm{~m}$ per annum, it comprises two distinct elements: a highprofile annual awards ceremony to celebrate prominent expatriates and other high-flying New Zealanders (see 'Capacity building', below), and a WCNZ network which links the 'top tier' of expatriates and 'friends of New Zealand' with a view to enhancing their engagement with and contribution to the country. WCNZ is jointly delivered with Kea, which has received around $\$ 1 \mathrm{~m}$ for the contract since 2005 (in addition to the $\$ 2.4 \mathrm{~m}$ in grants mentioned above). Beachheads is led by well-connected expatriates in offshore markets and aims to match high-potential New Zealand-based firms with mentoring from global business leaders (at an annual public cost of $\$ 1.2 \mathrm{~m}$ ongoing).

\section{Extending rights}

Four areas of government activity are relevant here. First is the right to vote, which New Zealand extends fairly expansively by international standards: both citizens and permanent residents can vote from abroad (for up to three years and one year after last departure, respectively). Second is the right to consular protection, which contrasts widely by consular post - from minimum services specified in the Vienna Convention on Consular Relations (United Nations, 1963) (such as in Sydney), to a much broader range of activities including outreach into expatriate communities (such as in London). Third are social rights, which New Zealand extends through a number of bilateral agreements on social security and pension transferability (though these are primarily negotiated to achieve fiscal net savings rather than in the interests of expatriates' rights as such).

Finally, two emerging discussions are relevant to external citizenship rights: one surrounds the intersection of population ageing and the needs of transnationally scattered families (for example, see Lunt, McPherson $\&$ Browning, 2006), and the other surrounds the development needs of Māori in Australia (Hamer, 2007). Such discussions have run parallel to one of the government's strategic themes (Families - Young and Old), but have not made a substantial impact on mainstream policy discussions; they take place against a background of emphasising celebration of 'talent' and counteracting the tall poppy syndrome, which tend to create the impression that all expatriates are successful (though actually there are also pockets of vulnerability that New Zealand 'owns' at least as much as it owns the 'World Class New Zealanders'). Nevertheless, as one senior analyst in the Ministry of Social Development put it (speaking unofficially), policy questions surrounding the diaspora revolve around the question, 'What can the expatriates do for us?'

\section{Capacity building}

This term refers to activities that promote national identity among emigrants, and to efforts at building state institutions dedicated to this population. Identityfostering activities include the offshore national events and celebrations supported to varying degrees by diplomatic and consular postings; the awards components of the World Class New Zealand programme mentioned 
above; and, at a more fundamental level, work on citizenship by descent within the Department of Internal Affairs (Identity Policy Team, 2006a, 2006b). The only two institution-building activities of note are DoL's time-limited expatriates programme and Kea (which is quasi-non-governmental), and there was been limited coherence between the two. Beyond these, activities that affect expatriates are fragmented and dispersed across government - having come into being at different times, for different reasons, in different locations within the state system - and there is no agency with responsibility for coherence among them.

In sum, although New Zealand has a relatively large number of programmes and activities that have an impact on the diaspora, these are dispersed widely across government. Prominent ideas regarding expatriates have been voiced in strategic plans about growth, innovation and economic transformation, but only small initiatives with relatively little coherence have fallen out of this rhetoric. How can this situation be explained? One plausible account is that it reflects the politicised nature of debate over emigration and expatriates: long-term brain drain fears, which peaked in 1999-2001, have forced government to respond to accusations of causing or allowing a brain drain, despite a lack of consensus about the exact nature of the 'problem', and what to do about it. Established tools to react have been noticeably absent, because New Zealand still sees itself essentially as a migrant-receiving country.

\section{Envisioning state-diaspora relations}

However, New Zealand is now also a substantial migrant-sending country, and this is unlikely to change any time soon. State-emigrant relations are an important channel through which migrant-sending states keep emigrants engaged in national development and block political accusations of causing/allowing brain drain. What kinds of long-term relationship could the New Zealand state have with its emigrants? To help stimulate thinking and discussion in this area, this article outlines three hypothetical scenarios regarding New Zealand's state-diaspora relations, based on the work of Peggy Levitt and Nina Glick-Schiller (Levitt \& Glick Schiller, 2004). Each scenario involves both threats and opportunities - these are not intended as policy options but rather as schemata within which different approaches and outcomes might be conceptualised.
In any of these scenarios, the diaspora is a source of pressures on political actors in the sending state. On one hand are economic pressures, motivating the government to economically incorporate expatriates as a way of boosting growth, and social pressures to redistribute wealth 'fairly' among members of the nation, motivating the government to extend rights to the diaspora. These two pressures tend to reinforce each other: attempts to extract economic benefits on the basis of shared identity generate demands for 'fairness' on the same grounds, and vice versa. On the other hand there are political pressures on the government - from both domestic and international sources - to limit governmental activity to the national territory. These take the form of accusations of interference from receiving states, and complaints from domestic actors against governments that seem to 'over-serve' emigrants. Thus, economic and social pressures are centrifugal, tending to stimulate engagement with the diaspora, while political pressures are centripetal, tending to constrain engagement.

In the first scenario, New Zealand is a transnational nation state, which treats its emigrants as long-term, long-distance members with undiminished rights and responsibilities attached to national belonging. In this scenario, the diaspora is integrated deeply into New Zealand's formal economic, political and sociocultural fields. New Zealand depends on the economic and political contributions of its diaspora and the state cultivates it attentively. New Zealanders abroad are hardwired into national governance processes, and consular officials are held somewhat responsible for protecting and representing them - though they also monitor and attempt to manipulate diaspora communities. The government cautiously avoids accusations of interference from host states and complaints from domestic electorates about over-serving emigrants.

In the second scenario, New Zealand is a strategically selective state, which encourages some form of longdistance economic and political nationalism but tries to selectively and strategically manage what emigrants can and cannot do. Recognising both the political and economic influence that emigrants wield, and the fact that many are unlikely to return, New Zealand's public institutions take steps to encourage emigrants to remain involved at home. However, the government exerts some control over their ties, trying to prevent 
the interests of emigrants from conflicting with those of the state. It switches between courting and milking elements of the diaspora, whichever is currently the most politically and economically expedient tactic. The transaction costs of frequently changing tack are significant: there are short-term opportunities for freeloaders to pose as representatives, and some more legitimate representatives are alienated by what they see as an exploitative attitude.

In the third scenario, New Zealand is a disinterested and denouncing state, which treats emigrants as if they no longer belong to their homeland. Some sections of the diaspora are deeply dissident: they see New Zealand's public institutions as illegitimate and act as a vocal opposition to the state, using their external positioning to foment internal conflicts and create international pressures to overturn and replace the New Zealand state. Overtures by New Zealanders abroad are viewed as suspect because migrants are seen as having turned their back on the homeland, or even as traitors to its cause. Emigration is the target of punitive policies, and it is made difficult for returnees to reintegrate.

These are not options, but scenarios, and each is contingent on more than state actions alone. This paper highlights only two broad options: either New Zealand can actively steer a course through these scenarios, or it can passively react to the increasingly transnational nature of its society. The latter approach seems to have avoided dispute recently, for two probable reasons. Firstly, 'replacement' migration has generated net population inflows, thus both masking emigration itself and allaying the associated economic fears by helping to sustain economic growth. Secondly, a sprinkling of (mostly cosmetic) programmes has had some success at deflecting the political heat on the government: the abolition of interest on student loans somewhat rebuts the charge that government is causing emigration, while the contrasting programmes in DoL and MED pacify different groups who demand different responses to emigration. However, this default approach seems a short-term game - one that may, in the long term, lead to an undesirable scenario.

\section{Conclusion}

While not a first-order policy issue in itself, the diaspora is a long-term feature of New Zealand's migration system and political landscape. There is little evidence to suggest that an economic turnaround, a worsening of the global instabilities precipitated by $9 / 11$, or even a contraction of global transport infrastructure in response to climate change and 'peak oil' would dramatically reduce the size of the diaspora or the significance of emigration within New Zealand's migration system. It is similarly unlikely that long-term brain drain fears are gone forever. The current economic upswing will end someday. 'Replacing' New Zealand citizen departures with new immigrants will continue to generate debates over transaction costs and social cohesion - and the next cyclical economic downturn will exacerbate the ugly xenophobic tone of these debates once again. New Zealand's brain drain debate will buzz into life again (when the theory comes back into vogue internationally, at least), and the current New Zealand government's somewhat half-hearted swatting tactics may not be sufficient to nail the sceptics next time round.

A coherent, holistic and long-term approach could help the state to reduce the downside of emigration and the diaspora - the recurrent political exposure to the charge of causing or allowing brain drain, and the costs incurred as a proportion of emigrants simply drift away and disengage with New Zealand permanently. Moreover, such an approach also has an open upside, when one looks at the successes of countries such as Israel, Ireland, India and China in 'leveraging' their diasporas. The first requirement of such an approach is to acknowledge that New Zealand's population is transnational, and to conceptualise the role of the state within it. This article has outlined some broad scenarios to contribute to a process of envisioning state-diaspora relations. Moreover, it suggests that now may be a sensible time to develop a coherent approach to state-diaspora relations: with economic growth currently reaching a peak and brain drain fears at a low point, there is some thinking space for decision makers to consider long-term strategies, instead of reacting to immediate political attacks or economic crises. This window of opportunity seems narrow, with economic storms on the horizon coming into an election year. In short, emigration management is a long game, and right now there is time to make hay while the sun shines.

\section{Acknowledgements}

I am very grateful to Paul Callister, Robert Didham, Gary Hawke, David Bromell, Jonathan Boston and 
Wynn Olsen for their comments and suggestions. Thanks also to Dayna Bradley and Nikitin Sallee of Kea New Zealand for providing financial data.

\section{References}

Australian Senate (2005) They Still Call Australia Home: inquiry into Australian expatriates, Canberra: Legal and Constitutional References Committee

Bain, H. (1996) 'PM makes furious attack on Peters', Dominion, 22 March, p.1

Barry, K. (2006) 'Home and away: the construction of citizenship in an emigration context', New York University Law Review, 81 (1), pp.11-59

Basch, L.G., N.G. Schiller \& C. Szanton Blanc (1994) Nations Unbound: transnational projects, postcolonial predicaments, and deterritorialized nation-states, Amsterdam: Gordon and Breach

Bauböck, R. (1994) Transnational Citizenship: membership and rights in international migration, Cheltenham and Northampton: Edward Elgar

Bauböck, R. (2005) 'Expansive citizenship: voting beyond territory and membership', Political Science and Politics, 38 (4), pp.683-87

Bedford, R. (2001) '2001: reflections on the spatial odysseys of New Zealanders', New Zealand Geographer, 57 (1), pp.49-54

Bedford, R., E. Ho \& G. Hugo (2003) 'Trans-Tasman migration in context: recent flows of New Zealanders revisited', People and Place, 11 (4), pp.53-62

Belich, J. (2001) Paradise Reforged: a history of the New Zealanders from the 1880s to the year 2000, Auckland: Allen Lane the Penguin Press

Betts, K. (2006) 'Introduction: diasporas, transnational citizenship and voting rights', People and Place, 14 (4), p. 25

Bryant, J. \& D. Law (2004) New Zealand's Diaspora and Overseas-born Population, working paper 04/13, Wellington: The Treasury

Butler, K. (2001) 'Defining diaspora, refining a discourse', Diaspora, 10 (2), pp.189-219

Button, D. (1988) 'Skilled Kiwis flock to QLD', Courier-Mail, 5 March
Carli, C. (2006. 'Italian citizenship and the transcending of territory', People and Place, 14 (4), pp.34-6

Carr, S., K. Inkson \& K. Thorn (2005) 'From global careers to talent flow: reinterpreting "brain drain", Journal of World Business, 40 (4), pp.386-98

Chamberlain, J. (2004) 'Gone to Oz: flight of the Kiwi', North \& South, 221, August, pp.34-45

Chamberlain, J. (2005) 'Kiwis come home, North \& South, 236, November, pp.34-46

Collins, S. (2002), 'Brain drain brings grant review', New Zealand Herald, 10 September

Cowen, B. (2002) Ireland and the Irish Abroad: report of the taskforce on policy regarding emigrants to the minister of foreign affairs, Dublin

Davenport, S. (2004) 'Panic and panacea: brain drain and science and technology human capital policy', Research Policy, 33 (4), pp.617-30

Davis, J. \& K. Thomas (2005) 'Brain drain "to get worse"', Press, 22 November

Deutsche Bank (2003) The New Zealand Economy and the Growth Debate, Deutsche Bank

Dumont, J.-C. \& G. Lemaître (2004) Counting Immigrants and Expatriates in OECD Countries: a new perspective, OECD

Dusevic, T. (2006) 'The Kiwis take wing,' Time Asia, 20 March, p.19

Fedi, M. (2006) 'Transnational citizenship: multiplicity of rights, responsibilities and opportunities', People and Place, 14 (4), pp.37-9

Fitzgerald, D. (2006) 'Rethinking emigrant citizenship', New York University Law Review, 81 (1), pp.90-116

Fullilove, M. \& C. Flutter (2004) Diaspora: the world wide web of Australians, New South Wales: Lowy Institute for International Policy, Longueville Media

Gamlen, A. (2005) The Brain Drain is Dead, Long Live the New Zealand Diaspora, vol. WP0510, Oxford: Centre on Migration, Policy and Society, University of Oxford

Gamlen, A. (2006) What are Diaspora Engagement Policies and What Kinds of States Use Them?, vol. WP0632, Oxford: Centre on Migration, Policy and Society, University of Oxford 
Goldring, L. (1998) 'From market membership to transnational citizenship?: the changing politicization of transnational spaces', L'Ordinaire Latino-American, 173-174, pp.167-72

Guarnizo, L. (1994) 'Los Dominicanyorks: the making of a binational society', Annals of the American Academy of Political and Social Sciences, 533, pp.70-86

Hamer, P. (2007) Mori in Australia: ng Mori i te ao moemoe, Wellington: Te Puni Kokiri

Hugo, G. (2005) 'Diaspora: an important and neglected dimension of Australia's demography', paper presented at the Population Association of America annual meeting, March-April, Philadelphia

Hugo, G. (2006a) 'An Australian diaspora?', International Migration, 44 (1)

Hugo, G. (2006b) 'Defining Australia's national population in the era of globalization', People and Place, 14 (4), pp.26-33

Hugo, G., D. Rudd \& K. Harris (2003) 'Australia's diaspora: it's size, nature and policy implications', CEDA information paper 80, Melbourne: CEDA

Identity Policy Team (2006a) An Analysis of New Zealand Citizenship by Descent, Wellington: Department of Internal Affairs

Identity Policy Team (2006b) Citizenship Issues for Maori Born Outside New Zealand, Wellington: Department of Internal Affairs

Jaspan, A. \& T. Colebatch (2007) 'New Zealand has reached a crossroad that has made it rethink its policies', The Age, 9 June, p. 5

Kymlicka, W. (1995) Multicultural Citizenship: a liberal theory of minority rights, Oxford: Clarendon Press

Laguerre, M.S. (1999) 'State, diaspora, and transnational politics: Haiti reconceptualised', Millenium: Journal of International Studies, 28 (3), pp.633-51

Lee, C. (2004) 'The transnationalization of citizenship and the logic of the nation-state', paper presented to the Asian-Pacific Sociological Association 6th conference on Asia-Pacific societies in globalisation, Seoul

Levitt, P. (1998) 'Social remittances: migration driven, local-level forms of cultural diffusion', International Migration Review, 32 (4), pp.926-48
Levitt, P. \& N. Glick Schiller (2004) 'Conceptualizing simultaneity: a transnational social field perspective on society', International Migration Review, 38 (3), pp.1002-39

Lunt, N., M. McPherson \& J. Browning (2006) Les Familles et Whanau sans Frontières: New Zealand and transnational family obligations, Wellington: Families Commission

McCrone, J. (2007) 'NZ slipping away from world, Press, 1 May, p. 5

McCurdy, D. (2004) 'Battling the academic brain drain', New Zealand Herald, 1 May

Migration DRC (2007) Global Migrant Origin Database, Development Research Centre on Migration, Globalisation and Poverty

New Zealand Herald (2007) 'How to stop the brain drain', 28 September, pp.1-37

Newland, K. \& E. Patrick (2004) Beyond Remittances: the role of diaspora in poverty reduction in their country of origin: a scoping study by the Migration Policy Institute for the Department of International Development, Washington DC: Migration Policy Institute/Department of International Development

Office of the Prime Minister (2002) Growing an Innovative New Zealand, Wellington: Office of the Prime Minister

Reis, M. (2004) 'Theorizing diaspora: perspectives on "Classical" and "contemporary" diaspora', International Migration, 42 (2), pp.41-60

Smith, R.C. (2003a) 'Diasporic membership in historical perspective: comparative insights from the Mexican, Italian and Polish cases,' International Migration Review, 37 (3), pp.724-59

Smith, R.C. (2003b) 'Migrant membership as an instituted process: transnationalization, the state and the extra-territorial conduct of Mexican politics', International Migration Review, 37 (3), pp.297-343

Spoonley, P., R. Bedford \& C. Mcpherson (2003) 'Divided loyalties and fractured sovereignty: transnationalism and the nation-state in Aotearoa/New Zealand', Journal of Ethnic and Migration Studies, 29 (1), pp.27-46

Sriskandarajah, D. \& C. Drew (2006) Brits Abroad: mapping the scale and nature of British emigration, London: Institute for Public Policy Research 
Statistics New Zealand (2006) Table 9.01: Permanent and long-term migration by country of citizenship, 1971-2006, in Tourism and Migration 2006, Wellington: Statistics New Zealand

United Nations (1963) Vienna Convention on Consular Relations

Van Hear, N., F. Pieke \& S. Vertovec (2004) The Contribution of UK-based Diasporas to Development and Poverty Reduction, Oxford: Centre on Migration, Policy and Society (COMPAS), University of Oxford

Vertovec, S. (2004) 'Migrant transnationalism and modes of transformation', International Migration Review, 38 (3), pp.971-1001

\section{TOWARDS A NEW GLOBAL CLIMATE TREATY: Looking Beyond 2012}

\section{An Institute of Policy Studies publication edited by Jonathan Boston}

Climate change poses huge ethical, political, economic and technical challenges. The global community had taken initial steps to address these challenges, but this falls far short of what will be needed in the years ahead. The Kyoto Protocol, negotiated in 1997 under the United Nations Framework Convention on Climate Change, requires industrialised countries to reduce their emissions by an average of $5 \%$ below 1990 levels during the first commitment period (2008-12). Most developing countries and all but two industrialised countries have ratified the Protocol - the exceptions being Australia and the United States.

With the first commitment period ending in barely five years, the international community must now decide what is the right mix of policies and commitments needed to build the momentum required to reverse the growth of greenhouse gas emissions and help nations adapt to the unavoidable impact of climate change. Much is at stake - not least the well-being of many future generations of humanity.

This book explores the critical policy issues that will need to be addressed during the forthcoming negotiations for a post-2012 climate treaty. Particular attention is given to the implications of such a treaty for New Zealand, including the issues affecting the energy, agricultural and forestry sectors.
Alan Gamlen is a New Zealand doctoral student in geography at Oxford University, funded by a Top Achiever Doctoral Scholarship and supervised by Steven Vertovec and Alisdair Rogers. His thesis focuses specifically on the emigration policies of migrant-sending states, though he works on migration, diasporas and transnationalism more broadly and has been researching and writing about the New Zealand diaspora since 2003.

The book is based on a series of roundtable discussions hosted by the Institute of Policy Studies in mid-2007. The roundtable series was sponsored by the chief executives of the New Zealand government departments and involved about 120 people drawn from a diverse range of stakeholder groups, sectors and communities of interest.

Contributors include Ralph Chapman, Pamela Chasek, Steve Hatfield-Dodds, Colin James, Lucas Kengmana, Adrian Macey and Murray Ward.

Jonathan Boston is Professor of Public Policy and Deputy Director of the Institute of Policy Studies. He has published widely in the fields of public management, tertiary education, social policy and comparative government.

Published - November 2007

Format - B5 Paperback, pp 258

ISBN - 1-877347-22-1

Price - $\$ 30.00$ (including P\&P within New Zealand)

To have a copy of Towards a New Climate Change Treaty: Looking Beyond 2012 and an invoice sent to you, please email, phone, fax or mail your order to:

Institute of Policy Studies

Victoria University of Wellington

Email ipos@vuw.ac.nz

Telephone +64 44635307

Fax +6444637413

P0 Box 600, Wellington

New Zealand 